\title{
Agenda-Setting and Framing Effects in Both the Vietnam and Iraq Wars
}

Noelle Forde

West Virginia University, npforde@mix.wvu.edu

Follow this and additional works at: https://researchrepository.wvu.edu/etd

\section{Recommended Citation}

Forde, Noelle, "Agenda-Setting and Framing Effects in Both the Vietnam and Iraq Wars" (2019). Graduate Theses, Dissertations, and Problem Reports. 4025.

https://researchrepository.wvu.edu/etd/4025

This Thesis is protected by copyright and/or related rights. It has been brought to you by the The Research Repository @ WVU with permission from the rights-holder(s). You are free to use this Thesis in any way that is permitted by the copyright and related rights legislation that applies to your use. For other uses you must obtain permission from the rights-holder(s) directly, unless additional rights are indicated by a Creative Commons license in the record and/ or on the work itself. This Thesis has been accepted for inclusion in WVU Graduate Theses, Dissertations, and Problem Reports collection by an authorized administrator of The Research Repository @ WVU. For more information, please contact researchrepository@mail.wvu.edu. 
Agenda-Setting and Framing Effects in the Vietnam and Iraq Wars

\author{
Noelle Forde
}

\author{
Thesis submitted \\ to the Reed College of Media \\ at West Virginia University \\ in partial fulfillment of the requirements for the degree of \\ Master of Science \\ in Journalism
}

Steve Urbanski, Ph.D., Chair

James Siekmeier, Ph.D.

Tom Stewart, M.S.J.

Gina Dahlia, M.S.J.

Department of Journalism

Morgantown, West Virginia

2019

Keywords: Vietnam War, Iraq War, Television News, Agenda-Setting, Framing Copyright 2019 Noelle Forde 


\section{ABSTRACT \\ Agenda-Setting and Framing Effects in the Iraq and Vietnam War}

\section{Noelle Forde}

This thesis is a content analysis of the news broadcasts of both the Vietnam and Iraq Wars. The research looks at nine news broadcasts from each of these wars. Two coders were asked to look for the different frames in each of these broadcasts. Both the media theories of agenda-setting and framing were used to support this research. 


\section{Table of Contents}

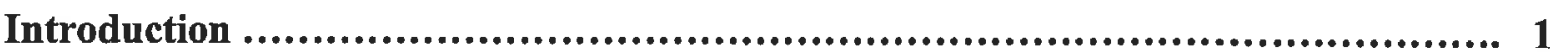

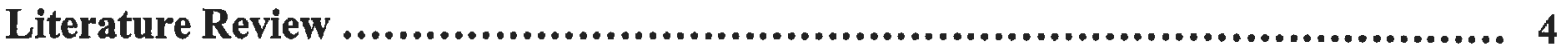

Research Questions ................................................................ 22

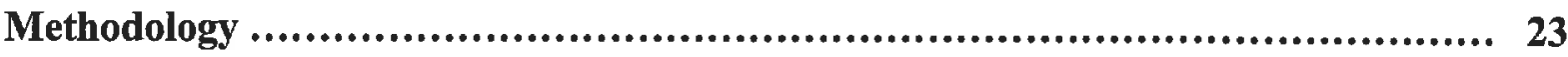

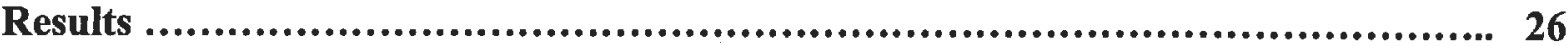

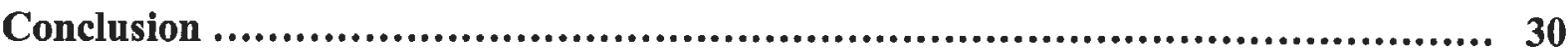

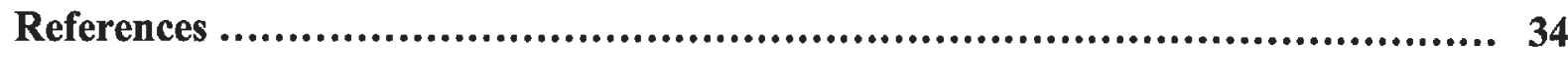

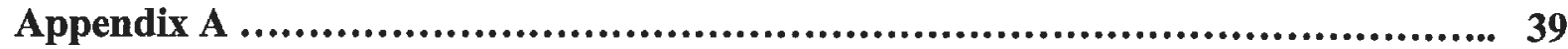

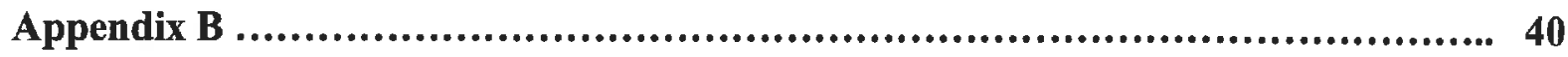

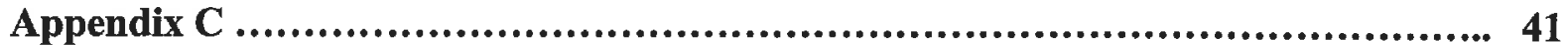




\section{Introduction}

Researchers have long studied the correlation between the public's opinion of war and the media's coverage of war. The effect of the media on public opinion is never more important than when the country is actually at war (Lewandowsky, Stritzke, Freund, Oberauer \& Krueger, 2013). This thesis will analyze the news coverage of the Vietnam and Iraq Wars in an effort to demonstrate any such correlation. It is important to note that the within study focuses on the second Iraq war begun by then-President George W. Bush in 2002. These two wars, Vietnam and Iraq II, were chosen specifically because of the extensive coverage by the television news media and the resulting data upon which to draw any conclusions.

It is noteworthy that while both of the subject wars began with high approval ratings by the public, such approval ratings in each of the wars began to drop drastically after combat began. The goal of this research is to see to what degree and in what manner media coverage affected the public's initial approval and subsequent decline in public approval in each of these wars. This research will incorporate the media theories of both agenda-setting and framing. This research will address three different research questions about these wars. The first being: How are the theories of agenda setting and framing prevalent in the news broadcasts of the Iraq War and Vietnam War? The second: How did the media coverage of the war in Vietnam differ from the coverage in Iraq? The third: Is there a correlation between the news coverage of the Vietnam and Iraq wars and the public's perception of these wars?

The Vietnam War era was known for its numerous protests. By its end, 60 percent of citizens said that it was a mistake to have sent troops into Vietnam. A Gallup Poll (Newport \& Carrol, 2005) compared the public's opinion of Vietnam during specific time frames in the war. 
Vietnam wasn't as heavily opposed in the earlier years. However, the disapproval rating climbed to 60 percent in the later years of the conflict.

The Iraq War also eventually had negative public approval. Like Vietnam, approval started out very high and then began to decline after conflict began. According to Mueller (2005), the public's approval of Iraq declined much quicker than it did in Vietnam. His research found that by early 2005 , when combat deaths were 1,500 , the percentage of respondents who considered the Iraq war a mistake was about the same as the percentage who considered the war in Vietnam a mistake at the time of the 1968 Tet Offensive, when nearly 20,000 soldiers had already died. Mueller concluded that the lower tolerance for casualties is largely due to the fact that the American public placed far less value on the purported stakes in Iraq than it did on those in Korea and Vietnam. The main threats Iraq thought to present to the United States when troops went in were weapons of mass destruction (WMDs) and support for international terrorism.

The graph below illustrates the decline of public support in both the Iraq and Vietnam Wars. Over three quarters of the country supported Iraq when the United States invaded. However, this number dropped to less than half of the country in only two years. Vietnam's number took a sharp decline after the Tet Offensive in 1968. 


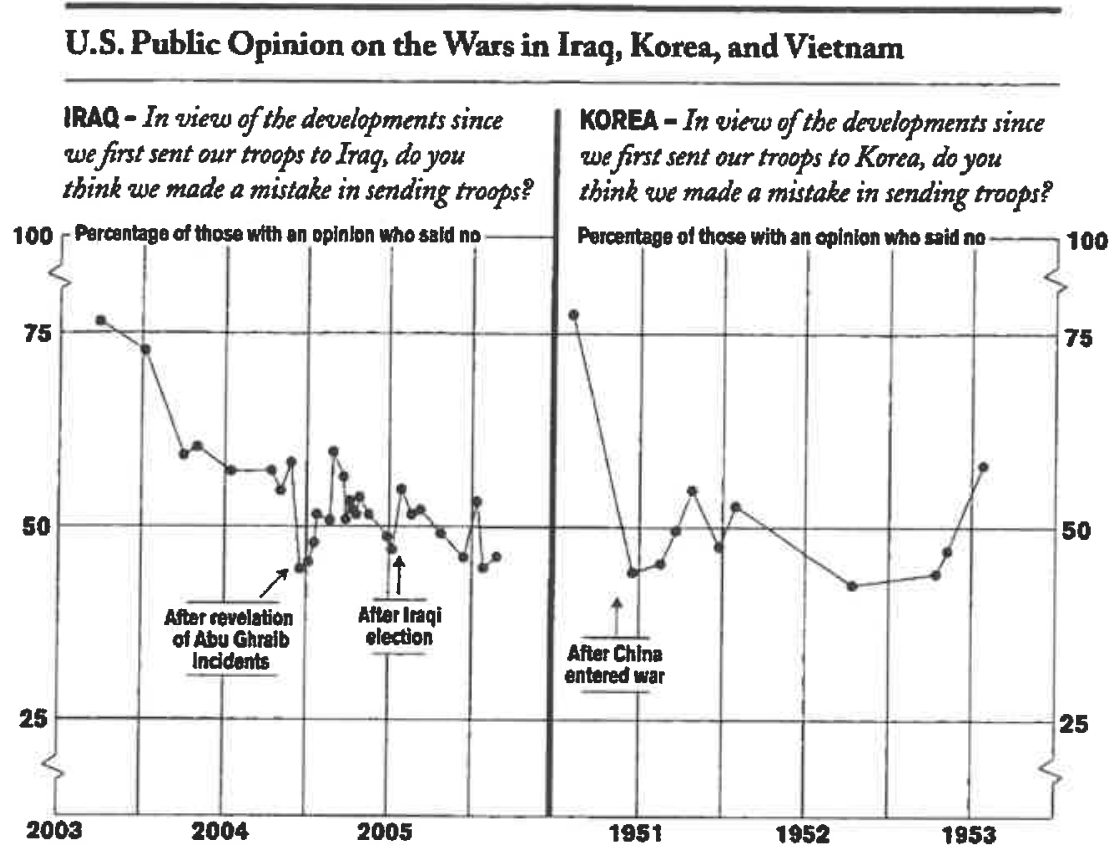

VITNAM - In view of the developments since we first sent our troops to Vietnam, do you think we made a mistake in sending troops?

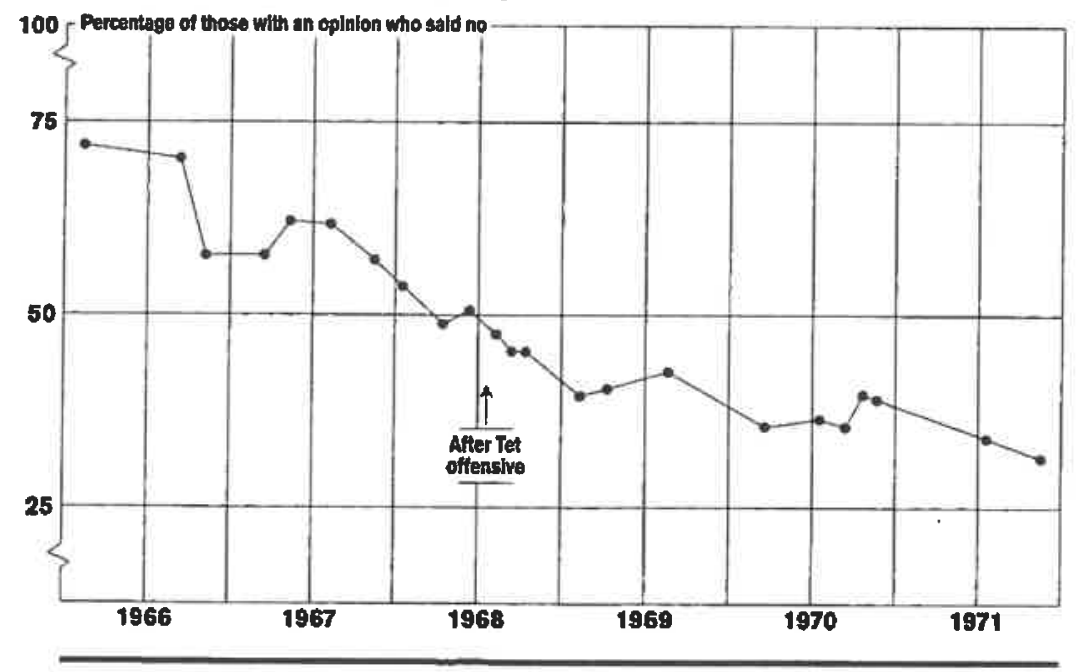

FOREIGN AFFAIRS - November/Dacember 2005 [47]

This research will evaluate television news coverage of both the Vietnam and Iraq War to measure the effects of the media on public opinion. It will further look at the different "frames" that the news media used in their coverage of these wars. It will provide an understanding of how 
varying levels of war coverage impacted Americans' opinions towards these wars. This research also will look for a correlation between the amount and content of media coverage of a war and the public's overall opinion of this war. These observations may be useful knowledge for journalists who may have, in the future, occasion to report about ongoing war activity. It may cause a journalist to contemplate their choices of framing during war when the public relies on journalists to report news, especially relating to war, in an unbiased manner.

The main component of the methodology will utilize a qualitative content analysis of news broadcasts from both the Vietnam and Iraq Wars. The news broadcasts will be obtained through the Vanderbilt Television News Archive. Broadcasts from CBS, ABC and NBC will be studied, since FOX and CNN did not exist in the Vietnam era. A separate coding sheet will be used, which can be found in Appendix A as well as a coding guide, which can be found in Appendix B. Two coders will be analyzing these broadcasts. Cohen's kappa will be used to measure intercoder agreement between the two coders. The statistics will be calculated using IBM's SPSS software.

\section{Literature Review}

News Coverage of Vietnam

The war in Vietnam was so heavily and extensively covered by the media, that one American infantryman said about the war, "Cameras. That's all I see wherever I look. Sometimes, I'm not sure whether I'm a soldier or an extra in a bad movie" (Stoler, 1986). Journalists were on the frontlines with the soldiers. It was an immersive style of reporting. The new television media gave people a deeper look at this conflict. The American public could view graphic images of soldiers being killed. 
The Vietnam War played a role in shaping American life in the 1960's and 1970's, along with the popularity of household television. Combined with trust in the government at an all-time low at this time, this was a recipe for a whirlwind of conflict (Hallin, 1984). Since Americans could not see the war firsthand, the only way that they were getting information on it was through the media. Their entire view of this war was dependent on how the media covered it, since Vietnam was thousands of miles away from the United States. However, extensive media coverage brought this war into the homes of almost every American. It is sometimes referred to as "The Living Room War" (Gelpi, 2010).

Michael Robinson's (1976) “Public Affairs Television and Political Malaise" presented data which concluded that people who watch television news tend to be more cynical of political institutions than those who consumed other media types. Television journalism also has been proven to be more influential to people. A study was done measuring people with varying levels of education and exposing them to different media channels. Television was the media most conducive to those with a lower education. The less-educated group could encode television media better than the more-educated groups. However, the less-educated group could not process newspaper and web media as well as the more-educated group. Education increases competence in processing print-based media. The-more educated groups benefitted more from print media while the less-educated groups did well with more audio-visual methods of media (Grabe, 2009).

Since its inception, television has been an instrumental tool for policy-makers to spread their ideas. In 1968, Democrats spent 61 percent of their campaign money on broadcasting. In 1972, two-thirds of the American people said that television was the best way to follow candidates for national office and more than half got their "clearest understanding of the candidates and issues in national elections" from television (Robinson, 1976). Robinson's data 
indicated that people who relied on television media tended to be more cynical of United States politics compared to those who looked at other forms of media.

It is important to note that television news in the 1960 s Vietnam era was very different from current television news. There were no specialized stations such as Fox, MSNBC, or CNN. At the time, CBS News was the largest network.

Walter Cronkite was a powerful and influential news anchor during the Vietnam era (Carlson, 2012). He was an American broadcast journalist who worked for CBS News. Both Cronkite and CBS were instrumental figures in the media coverage of the war. The network would broadcast reports from actual battles in Vietnam, illustrating to the public the very graphic realities of war.

Cronkite's nightly newscasts shaped public opinion about Vietnam (Carlson, 2012). Until 1968 , network news operations tended to edit out the graphic images and avoid direct criticism of the United States military. While there were no direct censorship laws, negative news reports infuriated then-President Lyndon Johnson (Achenbach, 2018).

Cronkite's trip to Vietnam in February 1968 and the hour-long prime-time broadcast that followed have been referred to as "the Cronkite Moment" (Achenbach, 2018). Like Vietnam, the Cronkite Moment remains controversial. It is at the center of the greater debate about news coverage of the war, and whether the media exposed troubles in Vietnam or undermined the American reasoning for entering the war (Achenbach, 2018). An excerpt from this broadcast can be found below.

We have been too often disappointed by the optimism of the American leaders, both in Vietnam and Washington, to have faith any longer in the silver lining they find in the darkest clouds. It would improve [the Communists] position and it would also require our realization, that we should have had all along, that any negotiations must be that - negotiations, not the dictation of peace terms. For it seems now more certain than ever that the bloody experience of Vietnam is to end in a stalemate. To say that we are closer to victory today is to believe, in the face of the 
evidence, the optimists who have been wrong in the past. To suggest we are on the edge of defeat is to yield to unreasonable pessimism. To say that we are mired in stalemate seems the only realistic, if unsatisfactory conclusion. On the off chance that military and political analysts are right, in the next few months we must test the enemy's intentions, in case this is indeed his last big gasp before negotiations. But it is increasingly clear to this reporter that the only rational way out then will be to negotiate, not as victors, but as an honorable people who lived up to their pledge to defend democracy, and did the best they could. This is Walter Cronkite. Good night (NPR, 1968).

This news broadcast from Cronkite came as a response to the controversial Tet Offensive attacks in Vietnam. On January $30^{\text {th }}, 1968$, Viet Cong forces attacked 13 cities in South Vietnam. Throughout the attack, fighting was abnormally fierce. In the three-week battle in Saigon, 1,000 Viet Cong troops fought 11,000 American troops to a stalemate, in the process killing or wounding 17,300 civilians while displacing 206,000 others and destroying 19,000 homes (Chomsky, 1978). Journalists caught many of these attacks on television, which were then broadcast to the public.

The Tet Offensive was a military success for the United States and South Vietnam. They managed to keep the Viet Cong from starting full-fledged rebellion in the South. However, the political effects that it had in the United States were drastic. In December 1967, a Gallup poll (Gillespie, 2014) found the American public almost evenly split on the question of whether sending troops to fight in Vietnam was a mistake. By August 1968, 53 percent thought sending troops was a mistake, versus 35 percent who said it wasn't. 


$\begin{array}{lccc}1968 \text { Aug 7-12† } & 53 & 35 & 12 \\ 1968 \text { Apr 4-9 } † & 48 & 40 & 12 \\ 1968 \text { Feb 22-27 } † & 49 & 41 & 10 \\ 1968 \text { Feb 1-6 } † & 46 & 42 & 12 \\ 1967 \text { Dec 7-12 } † & 45 & 46 & 9\end{array}$

According to Hallin (1963) television's coverage characteristics changed after Tet.

Specifically, war had been seen as a national endeavor, where Vietnam was reported as "our" war, while it was thereafter referred to as "the" war. This showed that journalists were distancing themselves from support of the war effort. The television coverage post-Tet also reported more on the costs of the war to American troops.

The United States government realized how much the media had control over the public's opinion of the war. After Cronkite told the public he did not support the war, President Johnson famously said, "If I've lost Cronkite, I've lost the War" (NPR, 1968). Johnson went as far as saying the television coverage of the war a big reason for him not seeking re-election. He stated:

As I sat in my office last evening, waiting to speak, I thought of the many times each week when television brings the war into the American home. No one can say exactly what effect those vivid scenes have on American opinion. Historians must only guess at the effect that television would have had during earlier conflicts on the future of this Nation: during the Korean war, for example, at that time when our forces were pushed back there to Pusan; or World War II, the Battle of the Bulge, or when our men were slugging it out in Europe or when most of our Air Force was shot down that day (Hallin, 1986, p. 157). 
This message was directed to a meeting of the National Association of Broadcasters.

Johnson implied in the above text that if television media existed in any previous wars, there was no way that these wars could be won. Additionally, the administration of then-President Richard Nixon, who succeeded Johnson in 1969, tried to manipulate public opinion in its own way.

Below is an excerpt from Hallin's (1984) study:

The key element in the Nixon administration's efforts to sell its Vietnam policy to the American public was Vietnamization - the replacing of American with Vietnamese troops. The data in Table 6 (below) suggest that the initiation of Vietnamization not only put the South Vietnamese armed forces on the news agenda, but also resulted in a continued preponderance of favorable references to their performance, despite the generally more critical tone of coverage in the latter part of the war. These favorable references were largely the result of what Daniel Boorstin (1962) has called "pseudo-events": statements by U.S. officials, ceremonies turning over U.S. bases to the South Vietnamese, etc. which because they represented official policy, were considered mandatory news stories (Hallin, 1984).

\section{TABLE 6}

Positive and Negative Refrzences to Performance of South Vietnamese Armed Forces, before and after Vietnamization

\begin{tabular}{|c|c|c|}
\hline & $\begin{array}{c}\text { Positive } \\
\text { REFERENCES }\end{array}$ & $\begin{array}{c}\text { Negative } \\
\text { REFERENCES }\end{array}$ \\
\hline Prior to Vietnamization & 11.5 & 3.0 \\
\hline After Vietnamization & 40.5 & 14.5 \\
\hline
\end{tabular}

As illustrated in the table above, news coverage of the South Vietnamize greatly increased after Nixon's Vietnamization speech. Both negative and positive mentions of the South Vietnamese increased. However, there was a larger increase of positive coverage by the media. 
Nixon created his own positive news story in Vietnam to try to increase the public's approval of his handling of the war. A study done by Katz (2017) collected poll data from both Gallup and White House polls. In these polls, the public was asked, "Do you support the handling of Vietnam by President Richard Nixon?" As shown in the graph below, the public's approval of Nixon's handling of the war increased 12 points after his Vietnamization speech.

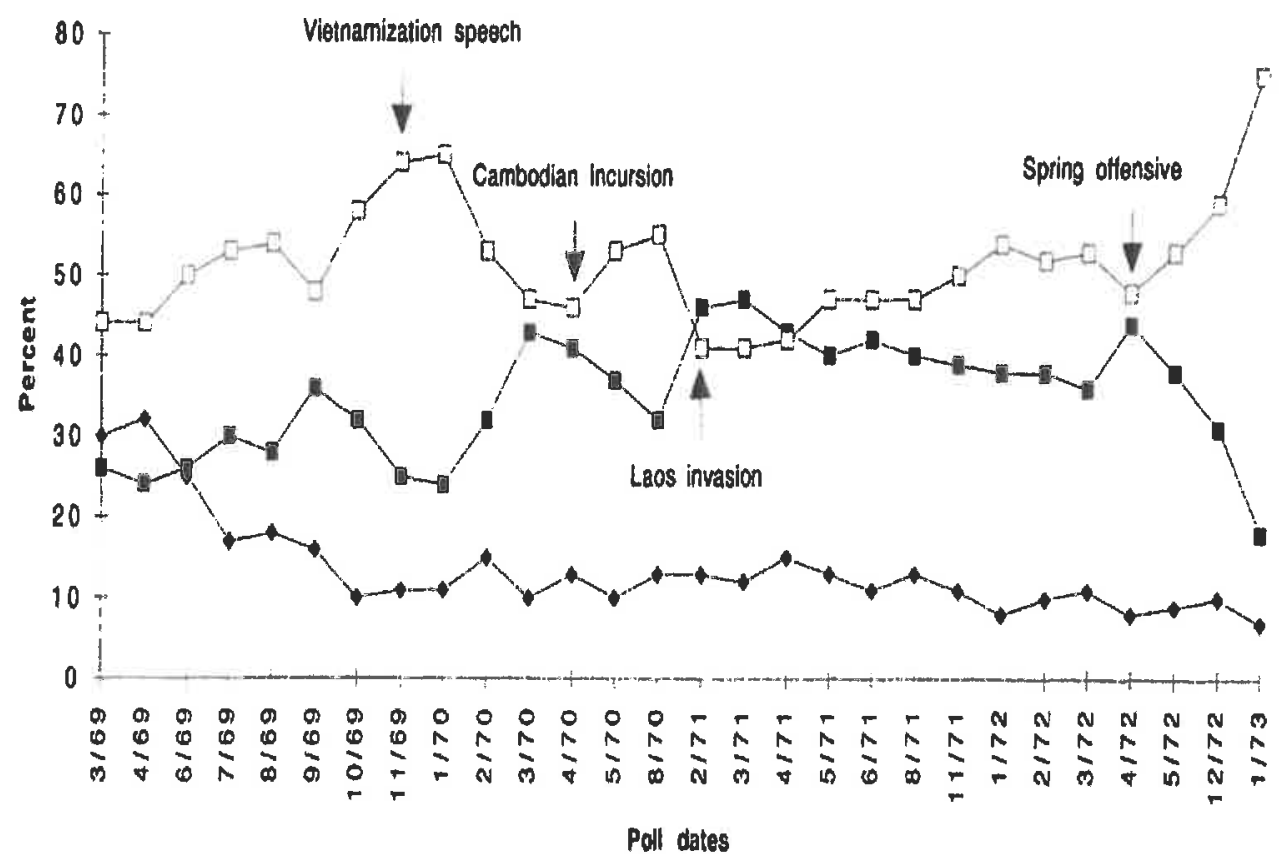

FIGURE 1. Ebb and flow of public support for Nixon's Vietnam Policy, as indicated by Gallup and ORC polls, 1969-73. ( $\square$, disapproval; $\square$, approval; $\downarrow$, no opinion) Note: Gallup and ORC used the same question to gauge public reaction: "Do you approve or disapprove of the way President Nixon is handling the Vietnam situation?" Entries for months when more than one poll was taken are averages. 
News Coverage of the Iraq War

The war in Iraq began in 2003. This came at a time when the media had even more means to broadcast as technology was better and television journalism was even more popular. However, as reported by American journalists, this war was covered differently by the news media than the Vietnam War (Okrent, 2004). The war in Vietnam allowed for more media coverage by journalists than Iraq. The U.S. military limited media access to military engagements after the Tet Offensive, as mentioned in the previous section, because of the negative tone of the coverage (Calabrese, 2005). The U.S. military limited media access in conflicts after Vietnam, largely because they concluded that an overly-open policy of media access turned the public against the Vietnam War.

The media coverage of Vietnam was a different phenomenon than the "embedded" journalists covering Iraq. The United States Department of Defense in 2003 defined a media embed as "a media representative remaining with a unit on an extended basis - perhaps a period of weeks or even months." This style of "embedded" journalism led to a more sanitized version of the war being shown by the media (Knightley, 2002). While foreign media outlets showed images of dead American soldiers in their media coverage, these images were not shown as frequently by the U.S. media, which focused more on issues such as weapons of mass destruction and the Al Qaeda-Iraq connection (Snow \& Taylor, 2006).

One study polled American people to assess their misperceptions about the war in Iraq (Kull, Ramsay \& Lewis 2004). The study compared the misbeliefs that people had about the war with their overall support of the war. The researchers asked people about three mistaken beliefs. The first was the link between Iraq and Al Qaeda, the second regarded Iraq's possession of 
weapons of mass destruction, and the third was the belief that world public opinion supported the United States entering this war. The results found a direct link between misperceptions and support for the war. The more misperceptions a person had, the more likely he or she was to support the war. This was the most powerful predictor. The second most powerful predictor was the person's intention to vote for the president. Those who planned to support George W. Bush were more likely to support the war than those intending to vote for Sen. John Kerry, the Democratic nominee. Those who followed the news on Iraq very or somewhat closely were 1.2 times more likely to vote for the war than those who did not follow it at all (Kull et al., 2004).

The study also researched people's misperceptions as a function of the news that they watched. 19 percent said that they primarily consumed print media while 80 percent consumed electronic. They were then asked from what source they got their broadcast news. The options were ABC, CBS, NBC, CNN, Fox News PBS and NPR. Finally, the researchers looked at how many misperceptions about the war these people had. They found that people who received their news from Fox News had the most misperceptions while NPR/PBS viewers had the least. There was no relationship between the level of attention to news and the misperceptions (Kull et al., 2010).

The same study then looked at the frequency of pro-war and anti-war commentators on the networks. They found that there was an overwhelming number of pro-war commentators. 81 percent of Fox's sources were pro-war, the highest of any network while CBS had 77 percent. NBC featured the lowest proportion of pro-war voices with 65 percent (Kull et al., 2004).

Additionally, the news reports covering the conflict in Iraq were found to contain many false statements. The nonpartisan Center for Public Integrity documented 935 false statements 
(in addition to hundreds more questionable claims) by top administration officials before the war regarding the threat from Iraq (Lewis \& Reading-Smith, 2008). Many of these statements were broadcast widely by U.S. media with little or no question of their integrity. The growing concerns even prompted the New York Times \& the Washington Post to publish self-reflective statements that acknowledged that their coverage of the Iraq War could have been better (Okrent, 2004). The Pew Research Center found that in 2010 , only one percent of news was dedicated to the war in Iraq. There was a conflict that year in the United States as to whether they should pull their troops out of Iraq. The public did not get that much information regarding this decision.

It is important to note that he reasons for the United States entering the Vietnam War were much different from the reasons for entering Iraq. The United States entered Iraq quickly citing national security concerns directly related to the terrorist attacks of September $11^{\text {th }} 2001$, otherwise referred to as 9/11. The National Strategy for Combating Terrorism (White House, 2006) defined the attacks of $9 / 11$ as - " "acts of war against the United States of America and its allies, and against the very idea of civilized society'. It identified the enemy as terrorism, an 'evil' threatening our 'freedoms and our way of life"'- (p. 1).

Gershkoff \& Kushner (2005) suggest that the War in Iraq received high levels of approval in its early days because the Bush Administration successfully framed the war as an extension of the U.S. response to the terrorist attacks of 9/11. At the beginning of this war, more than 70 percent of the American public supported it. They conducted a study measuring people's opinion of the war in its earlier days and compared it to Bush's mentions of terror when referring the Iraq War on television. As shown on the graph below, public approval tended to be higher the more then-President Bush referred to terror when speaking about the war on television. 


\section{Bush's rhetoric and public opinion}

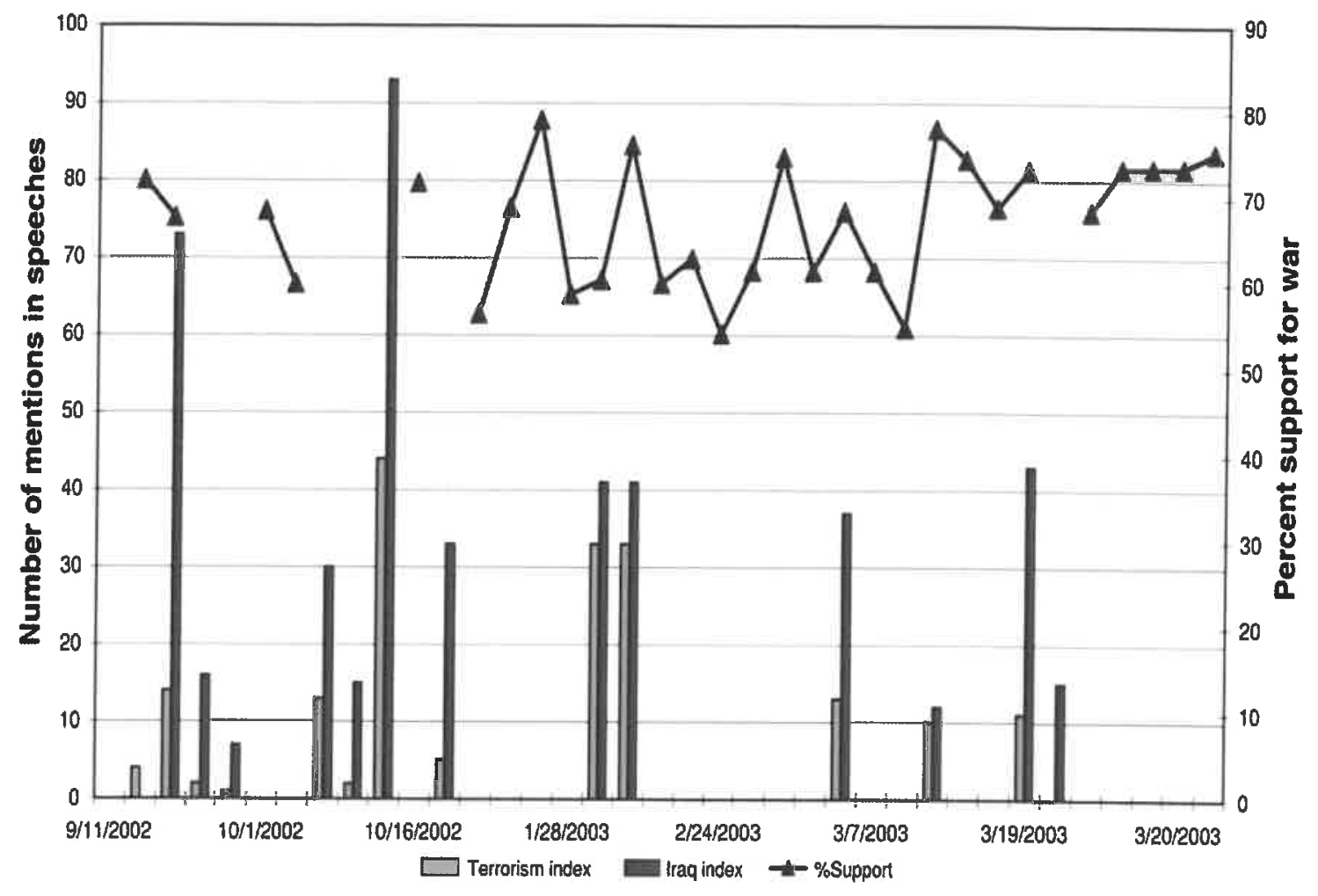

According to most theories of public opinion (Gershkoff \& Kushner, 2005) support for this war should have been extremely low. Many casualties were expected, most Americans anticipated a long conflict that would be detrimental to the U.S. economy. Protests broke out all around the world against this war.

President Bush never publicly blamed Iraq and Saddam Hussein for the $9 / 11$ events but he consistently linked Iraq with Al Qaeda and terror. Many Americans made the connection between them. The more people watched television news about the war in Iraq, the more they were exposed to the Bush administration's rhetoric. Gershkoff and Kushner (2005) proposed that the connection between Iraq and 9/11 made the latter the most relevant consideration in the 
minds of the American people when they thought about the war in Iraq, which increased support for the war.

The War on Terror was an important way that the United States justified the war in Iraq. The Bush Administration argued that it was our duty as Americans to invade. According to Reese and Lewis (2009), journalists shared that way of framing the war as indicated in their reports. They created a favorable news climate for military action in Iraq. This status quo frame of the War on Terror - pitting "us" vs. "them", obscuring concerns for state- sponsored violence, and being very vague about undifferentiated "terror" made it easier to regard Iraq as a legitimate response to $9 / 11$.

Mueller (2005) conducted a study measuring how effective the Bush administration was in getting the media to report on weapons of mass destruction, Iraq and Saddam Hussein. The study found that journalists covering this war tended to prioritize breaking-news stories and its "inverted pyramid" style of storytelling. This made the Bush administration's point of view on Weapons of Mass Destruction (WMD) issues more important at the expense of alternative perspectives and interpretations. Poor coverage of WMDs resulted less from outright political bias on the part of journalists, editors and producers than from the journalistic convention of always leading stories with what they thought of as the most "recent" and most "important" news coverage.

This method of news coverage ensured that the Bush administration's opinion and voice on issues of national security and intelligence would lead the news as long as the White House came out with a new message for each news cycle. This was reinforced by the lack of a strong political opposition in fall 2002 and spring 2003. The study also found that it was rare for even 
the reporters to critically question the political choices that linked 9/11, WMDs and Iraq in the "War on Terror." As a result, most American media did not act to check and balance the Bush Administration (Mueller, 2005).

It is important to note that this method of framing the war made it a very personal one for some Americans. The country had never seen a terrorist attack like 9/11.2,997 people lost their lives as a result of the attacks (Gershkoff \& Kushner, 2005). Thousands of others were injured. To this day, people are still getting sick and dying as a result of fume inhalation from the recovery efforts of $9 / 11$.

Although the war in Iraq had extremely high support in its earlier years, this support lowered much faster than in the earlier years of Vietnam. According to Mueller (2005) by early 2005 , when combat deaths were around 1,500, the percentage of respondents who considered the Iraq war a mistake was about the same as the percentage who considered the war in Vietnam a mistake at the time of the 1968 Tet Offensive, when nearly 20,000 soldiers had already died. Mueller (2005) states ${ }_{2}$ "This lower tolerance for casualties is largely due to the fact that the American public places far less value on the stakes in Iraq than it did on those in Korea and Vietnam. The main threats Iraq was thought to present to the United States when troops went in-weapons of mass destruction and support for international terrorism--have been, to say the least, discounted."

Kull et al (2004) proposes that the initial belief of the Iraq terrorism link and WMD was due to the media's coverage of these topics. They argue that the absence of something is not a good story while the prospect of something is. Reporters would only report on the possibility of WMD and the terrorism link because that is what is more newsworthy. 
Ethics of wartime news coverage

It is important to note that there are some ethical concerns as to whether war violence should be aired by the media. There is a valid argument that journalists are supposed to tell the truth about the world, no matter how harsh it is. In fact, the Society of Professional Journalists code of ethics says that journalists should "seek truth and report it" (SPJ, 2014). Major publications such as The New York Times and the Associated Press also have similar codes of ethics. The need for journalists to tell the truth during wartime is argued by journalist William Pronchau (Sperry 2005). He states that the United States being at war "raises to the very highest levels of national importance the responsibility of the American media not only to cover wars thoroughly, but as the nature of these wars change, to probe the war makers'--the civilian leadership's--reasons for waging them" (Prochnau, 1997, p. 329). Journalists also have an obligation to preserve the truth for historical reasons. A war photograph or news broadcasts can be seen as a piece of evidence from the war (Konstantinidou, 2008).

The argument against the media showing war images is rooted in national security fears. After the $9 / 11$ terrorist attacks, the Bush administration argued for the need to balance free speech with the right to protect sensitive information for national interest purposes (Strupp, 2005). For the wars in Iraq and Afghanistan, U.S. mainstream media often chose self-censorship over freedom of speech (Knightley, 2002). U.S. networks weighed aggressive coverage of the Afghan and Iraq War against the need to protect national security (Romano \& Albiniak, 2001). NBC news officials explained: "We all agree our responsibility as journalists is to inform the American public without endangering American lives" (Kiska, 2001, p. 2A). The struggle 
between free speech and national security concerns is a great problem that wartime journalists face.

Agenda-Setting and Framing

The notion of the media's effect on the public's opinion was first recognized in Walter Lippmann's book Public Opinion in 1922. Lippmann proposed that people are not able to effectively interpret their environment. It is the job of elites or media representatives to interpret the beliefs and motives of politicians. Cohen (1963) expanded this notion when he said, "The press is significantly more than a purveyor of information and opinion. It may not be successful much of the time in telling people what to think, but it is stunningly successful in telling readers what to think about" (p. 13). This became the basis for the agenda-setting media theory.

The term agenda-setting was coined by Maxwell McCombs and Donald Shaw in 1972. They called this study The Chapel Hill Study. It was based on the 1968 election. In this study, McCombs and Shaw found a link between press coverage and public opinion. They stated, "people learn from the media what the important issues are" (McCombs \& Shaw, 1972, p. 176).

The researchers interviewed registered voters during the 1968 presidential election and discovered what these people thought were the most important issues of the day. They analyzed local and national media coverage of the election. They measured the attention given to certain public issues such as civil rights, fiscal policy, foreign policy, and the war in Vietnam. They found correlations between pubic opinion of issues and media coverage and concluded this provided evidence of media agenda-setting (Neuman, 1990, p. 160-161). 
Framing takes agenda setting a step further. It is sometimes referred to as second-level agenda-setting. Framing theory suggests the way in which something is presented to the audience "the frame" influences how people process this information. This concept was first developed by Erving Goffman (1974) in his publication Frame Analysis.

A frame that has been shown to be effective in lowering the public's support for war is violence and, specifically, war casualties, according to John Mueller's (1973) book War, Presidents and Public Opinion. This study empirically demonstrated the relationship between increasing casualties and declining public support for the Korean and Vietnam Wars. Mueller concluded that "support for the wars followed to a remarkable degree the same trend pattern and was a function of the logarithm of the number of American casualties" (p. 266). Mueller also concluded that support tended to decline quicker in the beginning of each conflict than in the later stages of war. This is perhaps because the public became more desensitized to the war and its casualties as time went by and the war progressed.

Agenda-Setting in the Vietnam War

The Vietnam War seemed to be constantly on televisions in Americans homes. Whether people supported it or protested it, this war was on their minds. This is agenda-setting at play. Agenda-setting theory (McCombs \& Shaw, 1972) is interwoven into the news broadcasts of Vietnam. It suggests that it is the media that tells people the issues that are important. It was the constant coverage of Vietnam by the media that told people that it was an issue that they should think and care about. It resulted in the public formulating strong opinions about the war. Whether people wanted to or not, they discussed the war. 
The Vietnam War was given prevalent news coverage during its time. In the years 1968 until 1973, 24.5 percent of the news stories on CBS were Vietnam-related. On NBC, during the same time span, 22 percent were Vietnam-related stories. This means that almost a fourth of all news stories were about the Vietnam War (Patterson, 1984). As the media began to cover the Vietnam War more often, the percentage of the U.S. public who thought of the Vietnam War as the most important problem at the time rose to over 50 percent (Dearing \& Rogers, 1996). This meant that American politicians had to prioritize the Vietnam War over other important issues in the 1960's, such as race relations, campus unrest, urban riots, and inflation (McCombs, 2004).

Walter Cronkite's broadcast about the Tet Offensive is a direct example of agendasetting. In December 1967, a Gallup poll found the American public almost evenly split on the question of whether sending troops to fight in Vietnam was a mistake. By August 1968, 53 percent thought sending troops was a mistake, versus 35 percent who had previously said it was not. The Tet Offensive was not, technically, a military loss for the United States. But, Cronkite's broadcast made it a detrimental political loss to the United States Military.

Agenda-Setting in the Iraq War

The public's approval of the Iraq War was the highest in its earliest days. According to Mueller (2005), the war had an approval rating above 75 percent in 2003. The Bush Administration attempted to build a Congressional and societal consensus for war in Iraq in the Fall of 2002. However, the United States did not go to war in Iraq until March $19^{\text {th }}, 2003$. The Bush Administration began to push for a declaration of war in the Fall of 2002. The first time weapons of mass destruction was spoken was during an interview with CNN's Wolf Blitzer on 
September 8, 2002, when Condoleeza Rice, National Security Advisor to the president, on the case for preemptive war, said:

We know that he [Saddam] has the infrastructure, nuclear scientists to make a nuclear weapon. And we know that when the inspectors assessed this after the Gulf War, he was far, far closer to a crude nuclear device than anybody thought, maybe six months from a crude nuclear device... There will always be some uncertainty about how quickly he can acquire nuclear weapons. But we don't want the smoking gun to be a mushroom cloud (Cerf \& Navasky, 2008, p. 8).

President Bush then made a statement warning the American public about the threat that Saddam's WMDs posed to the American public (Cerf \& Navasky, 2008). These statements and others during this period would mark the beginning of a high concentration of what the Center for Public Integrity called "false statements," in its 2008 report titled, "Iraq--The War Card: Orchestrated Deception on the Path to War." The report cited 935 "false statements" made by President Bush and seven of his top advisors about the threat posed by Saddam Hussein and his link to al Qaeda in the two years following September 11th, 2001 (Lewis \& Reading-Smith, 2008, para. 1).

The statements tracked by the Center for Public Integrity spiked at the end of 2002 and the beginning of 2003, as did the public's perception about whether Iraq had WMDs and if the American public was in danger. For example, when the number of "false statements" spiked in September 2002 to more than 60, according to The War Card report, respondents who believed that Iraq had WMDs also increased. However, in December 2002, when the number of "false statements" dropped to 20 (an 11-month low for the period of September 2002 through July 
2003), as did the percent of respondents who agreed Iraq has WMD. (Lewis \& Reading-Smith, 2008, para. 13). This poll shows a correlation between the media coverage of the Iraq War and the public's perception.

The media also broadcast content about Iraq more frequently in its earlier days.

The Center for Public Affairs (2003) studied the news coverage of the Iraq War for a span of 26 days between March 20 and April 14, 2003. CBS devoted the least coverage to the conflict with 234 stories, representing six hours and 11 minutes of airtime. ABC came next with 274 stories and seven hours and seven minutes of airtime. Among the broadcast networks, NBC carried the most war coverage, with 295 stories lasting eight hours and 33 minutes. FOX's evening news show devoted many more stories (328) and much more time (14 hours and 19 minutes) to the conflict than any of the network news. The war accounted for 95 percent of all stories on the FOX newscast, compared to 88 percent on $\mathrm{ABC}, 85$ percent on NBC, and 77 percent on CBS. According to the Pew Research Center, in 2003, the war in Iraq had a public approval rating of 72 percent. The news coverage of this war steadily began to decline. In 2010, the Pew Research Center (2014) stated that only one percent of news was dedicated to Iraq. The war was still going on at this time as it was not formally ended until August $31^{\text {st }}, 2011$.

\section{Research Questions}

This thesis will address the following research questions:

RQ1: How are the theories of agenda setting and framing prevalent in the news broadcasts of the Iraq War and Vietnam War?

RQ2: How did the media coverage of the war in Vietnam differ from the coverage in Iraq?

RQ3: Is there a correlation between the news coverage of the Vietnam and Iraq wars and the public's perception of these wars? 


\section{Methodology}

This research is a qualitative content analysis of news broadcasts from both the Vietnam and Iraq wars. These news clips were obtained from the Vanderbilt Television News Archive, the world's most extensive and complete archive of television news.

The Vietnam War lasted 20 years while the conflict in Iraq lasted seven. Since there are thousands of news broadcasts to look through during this time period, the two specific time periods to be investigated were the last four years of each conflict. Another key reason to narrow and focus the search is because the Vanderbilt News Archive began archiving broadcasts in 1968.

There are numerous varying arguments as to when the conflicts in Vietnam and Iraq ended. For purposes of this research, January $27^{\text {th }}, 1973_{2}$ was used as the final date of the Vietnam War. This is the date that former U.S. President Nixon signed the Paris Peace Accords, officially titled the Agreement on Ending the War and Restoring Peace in Vietnam to establish peace in Vietnam and end the Vietnam War. For this research, August $31^{\text {st }}, 2010_{2}$ was considered the final date of the Iraq War. This is the date that former U.S. President Barack Obama formally declared the war in Iraq to be over.

These broadcasts were randomly selected from the Vanderbilt News Archive. For the Vietnam War broadcasts, the key word "Vietnam War" was typed in. The dates chosen were from January $27^{\text {th }}, 1969$ to January $27^{\text {th }}, 1973$. The news networks were then chosen (CBS, ABC, NBC). The news clips were listed in order of relevance to the topic. Only news clips between one minute and thirty seconds and three minutes and thirty seconds were considered. The first 20 clips that met the criteria were assigned numbers and then entered into random.com. Three clips from each network were selected. This test was used for all three networks to randomly decide 
which clips will be researched. The same test was done for the Iraq War news broadcasts except the key words were "Iraq War" and the dates were changed to August $31^{\text {st }}, 2006$, to August $31^{\text {st }}$, 2010.

A separate coding sheet can be found in Appendix A. The author and second coder analyzed the videos and filled out separate coding sheets. These responses were then tested for intercoder reliability using Cohen's kappa. IBM's SPSS software was used to analyze this data. A separate coding book (Appendix B) was used to help explain the coding sheet more in depth. The separate coder was adequately trained and knowledgeable about the research being conducted.

The specific news broadcasts that were looked at for coverage of the Vietnam War are listed as follows:

COMMENTARY (VIETNAM WAR) \#20553

ABC Evening News for Thursday, May 11, 1972

VIETNAM WAR \#15519

$A B C$ Evening News for Tuesday, May 18, 1971

COMMENTARY (NIXON, VIETNAM) \#8203

$A B C$ Evening News for Wednesday, Oct 07, 1970

ANALYSIS (VIETNAM WAR) \#215822

CBS Evening News for Wednesday, Mar 03, 1971

ANALYSIS (VIETNAM WAR) \#222570

CBS Evening News for Monday, Apr 17, 1972

VIETNAM / VIET CONG / KY / FIGHTING / ATROCITIES \#201418

CBS Evening News for Wednesday, Nov 05, 1969

JOURNAL (VIETNAM WAR CASUALTIES) \#459934

NBC Evening News for Thursday, Sep 02, 1971 
VIETNAM / WAR REPORT \#445417

NBC Evening News for Monday, Apr 07, 1969

VIETNAM / PEACE TALKS \#461459

NBC Evening News for Sunday, Nov 19, 1972

The specific news broadcasts that were looked at for coverage of the Iraq War are listed as follows:

IRAQ WAR / BUSH'S CASE \#837766

ABC Evening News for Thursday, Aug 31, 2006

IRAQ WAR / OBAMA SPEECH \#973065

$A B C$ Evening News for Sunday, Aug 22, 2010

IRAQ WAR / BOMBINGS / PETRAEUS INTERVIEW \#899968

$A B C$ Evening News for Monday, Jul 28, 2008

IRAQ WAR / JOURNALISTS WAR STORIES \#855284

CBS Evening News for Tuesday, Mar 20, 2007

IRAQ WAR / CASUALTIES / FUNDING BILL \#857332

CBS Evening News for Tuesday, Apr 10, 2007

IRAQ WAR / TROOP WITHDRAWAL \#971698

CBS Evening News for Monday, Aug 02, 2010

IRAQ WAR / TERRORISM \#973542

NBC Evening News for Saturday, Aug 28, 2010

IRAQ WAR / OBAMA TRIP \#899226

NBC Evening News for Sunday, Jul 20, 2008

IRAQ WAR / FUNDING \#871040

NBC Evening News for Friday, May 25, 2007 


\section{Results: Framing of Iraq and Vietnam Wars}

The most notable differences between the framings of these two wars were in the frames of American patriotism and national security. Coder 1 and Coder 2 were in perfect agreement that all nine of the Iraq news broadcasts contained the framing elements of both American patriotism and national security.

National Security- Iraq

\section{VAR00001 * VAR00002 Crosstabulation}

\begin{tabular}{lccc} 
Count & & & \\
& & & \\
& VAR00002 & \\
& present & Total \\
\hline VAR00001 & present & 9 & 9 \\
\hline Total & & 9 & 9 \\
\hline
\end{tabular}

\section{Symmetric Measures}

\begin{tabular}{lcc} 
& \multicolumn{2}{c}{ Value } \\
\hline Measure of Agreement & Kappa & $\cdot^{\mathbf{a}}$ \\
\hline N of Valid Cases & 9 \\
\hline
\end{tabular}

a. No statistics are computed because VAR00001 and VAR00002 are constants. 
American Patriotism- Iraq

Symmetric Measures

\begin{tabular}{lrr} 
& \multicolumn{2}{c}{ Value } \\
\hline Measure of Agreement & Kappa & $\cdot^{\mathrm{a}}$ \\
\hline N of Valid Cases & & 9 \\
\hline
\end{tabular}

a. No statistics are computed because

VAR00001 and VAR00002 are constants.

\section{VAR00001 * VAR00002 \\ Crosstabulation}

\section{Count}

\begin{tabular}{lrrr} 
& \multicolumn{2}{c}{$\begin{array}{c}\text { VAR00002 } \\
\text { present }\end{array}$} & \multicolumn{1}{c}{ Total } \\
\hline VAR00001 & present & 9 & 9 \\
\hline Total & & 9 & 9 \\
\hline
\end{tabular}

These frames were not as prevalent in the Vietnam War broadcasts. As shown in the crosstables below, Coder 1 observed the American patriotism frame present in only four out of nine of these broadcasts. Coder 2 saw this frame in five out of nine broadcasts. The kappa value computed was .780 which makes this statistically significant. According to Cohen's kappa any kappa value between .061 and .80 has substantial significance. 


\section{VAR00001 * VAR00002 Crosstabulation}

\section{Count}

\begin{tabular}{llrrrr} 
& \multicolumn{4}{c}{ VAR00002 } \\
& & not & present & Total \\
\hline \multirow{2}{*}{ VAR00001 } & not & 4 & 1 & 5 \\
\cline { 2 - 6 } & present & 0 & 4 & 4 \\
\hline Total & & 4 & 5 & 9 \\
\hline
\end{tabular}

\section{Symmetric Measures}

\begin{tabular}{lrrrrr} 
& Value & $\begin{array}{c}\text { Asymptotic } \\
\text { Standard } \\
\text { Error }^{\mathrm{a}}\end{array}$ & $\begin{array}{c}\text { Approximate } \\
\mathrm{T}^{\mathrm{b}}\end{array}$ & $\begin{array}{c}\text { Approximate } \\
\text { Significance }\end{array}$ \\
\hline Measure of Agreement & $\mathrm{Kappa}$ & .780 & .202 & 2.400 & .016 \\
\hline N of Valid Cases & 9 & & & \\
\hline
\end{tabular}

a. Not assuming the null hypothesis.

b. Using the asymptotic standard error assuming the null hypothesis.

The frame of national security was even less prevalent in the Vietnam broadcasts. As show in the cross tables below, Coder 1 observed this frame in two of the broadcasts while Coder 2 observed the frame in three. This analysis had a kappa value of .727 which gives it substantial significance according to Cohen's kappa. 


\section{VAR00001* VAR00002 Crosstabulation}

Count

\begin{tabular}{|c|c|c|c|c|}
\hline & \multicolumn{4}{|c|}{ VAR00002 } \\
\hline & & not & present & Total \\
\hline \multirow[t]{2}{*}{ VAR00001 } & not & 6 & 1 & 7 \\
\hline & present & 0 & 2 & 2 \\
\hline Total & & 6 & 3 & 9 \\
\hline
\end{tabular}

Symmetric Measures

\begin{tabular}{|c|c|c|c|c|c|}
\hline & & Value & $\begin{array}{l}\text { Asymptotic } \\
\text { Standard } \\
\text { Error }^{\mathrm{a}}\end{array}$ & Approximate & $\begin{array}{l}\text { Approximate } \\
\text { Significance }\end{array}$ \\
\hline Measure of Agreement & Kappa & .727 & .247 & 2.268 & .023 \\
\hline $\mathrm{N}$ of Valid Cases & & 9 & & & \\
\hline
\end{tabular}

a. Not assuming the null hypothesis.

b. Using the asymptotic standard error assuming the null hypothesis.

Gershkoff \& Kushner (2005) showed how President Bush clearly framed the Iraq strategy within the War on Terror by justifying Iraq with $9 / 11$. He stated that 'The battle of Iraq is one victory in a war on terror that began on Sept. 11, 2001, and still goes on (Benedetto \& McQuillan, 2003). Public support for the war was based on whether one believed the link between 9/11 and Saddam Hussein, which a majority of Americans did.

The news broadcasts observed in this study all showed elements of American patriotism and national security. The media portrayed an element of danger for Americans with the national security frame. The terrorist attacks of $9 / 11$ were still recent at this time. It is understandable how 
the American public believed this, even with little proof. This method of framing the war could have a been reason why the war had such a high level of initial support. This could also explain why the war had such a sharp decline in support so early on (Mueller, 2005).

A majority of the Vietnam and Iraq War broadcasts contained the frames of military conflicts and violent/graphic images. This disproves the theory that the Vietnam War contained more graphic and violent images than its Iraq counterpart. Both of these wars were framed as violent, military conflicts.

The frame of economic consequences was slightly more prevalent in the Iraq broadcasts. However, it was not enough to be significant. The frame of protest also appeared slightly in both, however it does not have significance. A full list of the statistical tables can be found in Appendix C.

\section{Conclusion}

The media theories of agenda-setting and framing are prevalent in both the Iraq and Vietnam Wars. These wars were both extensively broadcasted by the media during their respective times. The news coverage of the wars in Iraq and Vietnam had many similarities as they were both covered as important military conflicts.

The main difference between the framing of televisions coverage of the Iraq and Vietnam wars was the frames of American patriotism and national security. The Bush Administration justified the Iraq War by claiming that the American public was in danger and they had a duty to invade in Iraq (Gershkoff \&_Kushner 2005). 
The research in the compiled literature review also shows a direct correlation between the media coverage of these wars and the public's perception. As the media covered certain time periods and events during these wars, the public perception of these events changed.

However, in the case of the Iraq War, the government's push to frame the war may have backfired. Since Americans based their approval on theories that did not have much substantial proof, their approval went down as their beliefs in WMDs and the terrorism connection to Iraq went down. According to a 2019 Gallup poll, only 18 percent of people have a favorable view of the War in Iraq while 79 percent do not have a favorable view.

This research also discovered an interesting difference between the public's support for the Iraq and Vietnam Wars. The Democratic and Republican parties in the United States became much more polarized in their public approval during the Iraq War.

According to the Pew Research Center graph below, Americans were split on party lines more drastically for the Iraq War than the Vietnam War. The table below shows that towards the end of the Iraq War, only 14 percent of Democrats supported the War compared to 73 percent of Republicans. The parties were more evenly split with their support of the Vietnam War. While Republicans still supported the war at a higher rate than Democrats, the difference was not as significant. There was an 11 percent difference between the two parties for the Vietnam War while the Iraq War had a 59-point difference. The growing opposition between the two political parties is a potential future topic for further research. The Iraq War was seemingly much more politically driven than Vietnam. 

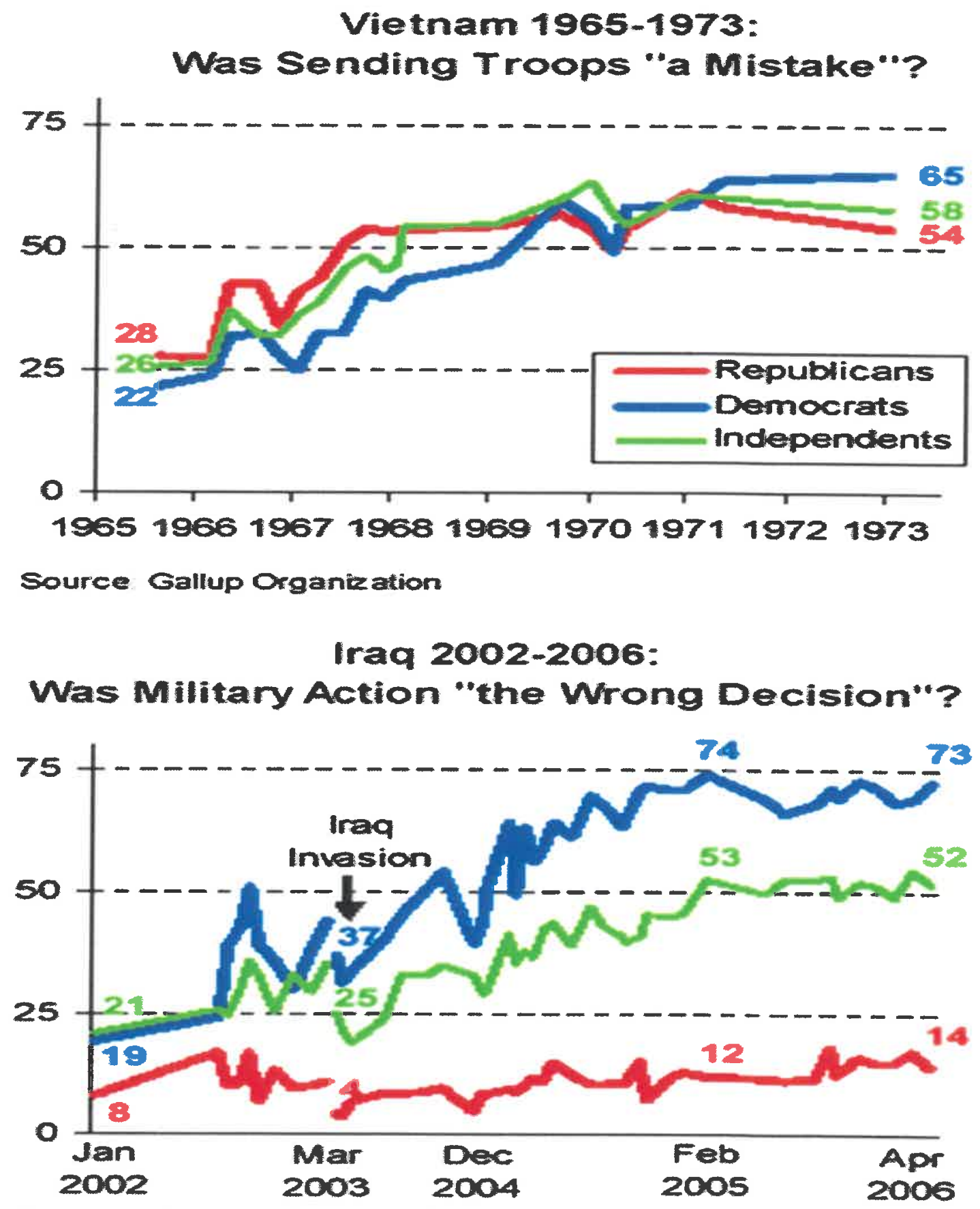

Pre-war. Fercent "opposed" to tabng miltary action in Iraq. Post-mar. Percent baying $2 w$ as the Wrong decision".

Source. Pew Research Center for the People \& the Press

The news coverage of these wars had many similarities and differences that were highlighted in the above literature. The media theories of both agenda-setting and framing were prevalent in both of these wars. However, they presented themselves differently in the two wars. 
Namely, in Iraq, the media participated in the U.S. government's attempt to set the agenda, and frame the issues, to building U.S. support for the War.

This research can conclude that the media coverage of these wars affected the public opinion. There has been extensive prior research that proves agenda-setting and framing are both effective in helping to shape the public's opinion. Since these theories were prevalent in the television news broadcasts of both of these wars, it can be concluded that they were effective in shaping the public's opinion of the wars. 


\section{References}

Achenbach, J. (2018, May 25). Did the news media, led by Walter Cronkite, lose the war in Vietnam? Retrieved from https://www.washingtonpost.com/national/did-the-newsmedia-led-by-walter-cronkite-lose-the-war-in-vietnam/2018/05/25/a5b3e098-495e-11e8$\underline{827 \mathrm{e}-190 \text { efaflflee_story.html?utm_term }=.74 \mathrm{~b} 624555018}$

Albiniak, P \& Romano, A. (2001, October 15). TV's balancing act. Online magazine of Broadcasting \& Cable.

Allen, B., Oloughlin, P., Jasperson, A., \& Sullivan, J. L. (1994). The Media and the Gulf War: Framing, Priming, and the Spiral of Silence. Polity, 27(2), 255-284. doi:10.2307/3235175

Alan, Jeff., and James M. Lane. Anchoring America: The Changing Face of Network News. Chicago, IL: Bonus Books.

Allenby, B. b. (2017). The Age of Weaponized Narrative or, Where Have You Gone, Walter Cronkite? Issues In Science \& Technology, 33(4), 65-70

Belknap, M. (2001). The CNN Effect: Strategic Enabler or Operational Risk? 34. Army War College.http://ssi.armywarcollege.edu/pubs/parameters/articles/02autumn/belknap.pdf

Benedetto, R., \& McQuillan, L. (2003, May 02). Bush hails win, looks ahead. USA Today.

Calabrese, M. (2005). Emerging threats and the war on terrorism the formation of radical Islamist movements in Sub-Saharan Africa. Monterey California. Naval Postgraduate School.

Calvert, C. (2012). Staring Death in the Face during Times of War: When Ethics, Law, and SelfCensorship in the News Media Hide the Morbidity of Authenticity, 25 Notre Dame J.L. Ethics \& Public Policy 87

Carlson, M. (2012). Rethinking Journalistic Authority, Journalism Studies, 13:4, 483498, DOI: $\underline{10.1080 / 1461670 X .2011 .642250}$

Cerf, C. \& Navasky, V. (2008). Mission accomplished! Or how we won the war in Iraq. New York: Simon \& Schuster.

Chomsky, N. (1978). The US media and the Tet offensive. Race \& Class, 20(1), 2139. https://doi.org/10.1177/030639687802000102 
Cohen, B.C. (1963). The press and foreign policy. Princeton, NJ: Princeton University Press.

Dearing, James W., Rogers, Everett M. Agenda-Setting. Thousand Oaks, CA: Sage Publications, 1996.

Fahmy, S. (2005). Photojournalists' and Photo Editors' Attitudes and Perceptions: The Visual Coverage of 9/11 and the Afghan War. Visual Communication Quarterly, 12(3/4), 146-163. https://doi.org/10.1207/s15551407vcq1203\&4pass:[ ]4

Fairhurst, G. T., \& Sarr, R. A. (1996). The art of framing: Managing the language of leadership. American Journal of Health-System Pharmacy, 53(21), 2670-2671. doi:10.1093/ajhp/53.21.2670

Gelpi, C (2010). Performing on cue? The formation of public opinion toward war. https://doi.org/10.1177/0022002709352845

Gershkoff, A., \& Kushner, S. (2005). Shaping Public Opinion: The 9/11-Iraq Connection in the Bush Administration's Rhetoric. Perspectives on Politics, 3(3), 525-537.

doi:10.1017/S1537592705050334

Gillespie, M. (2014, October 18). Americans Look Back at Vietnam War. Retrieved from https://news.gallup.com/poll/2299/americans-look-back-vietnam-war.aspx

Grabe, M. E., Kamhawi, R., \& Yegiyan, N. (2009). Informing Citizens: How People with Different Levels of Education Process Television, Newspaper, and Web News. Journal Of Broadcasting \& Electronic Media, 53(1), 90-111. doi:10.1080/08838150802643860

Hallin, D. (1984). The Media, the War in Vietnam, and Political Support: A Critique of the Thesis of an Oppositional Media. The Journal of Politics, 46(1), 2-24. Retrieved from http://www.jstor.org/stable/2130432

Hartnett, S. J., \& Stengrim, L. A. (2004). "The Whole Operation of Deception": Reconstructing President Bush's Rhetoric of Weapons of Mass Destruction. Cultural Studies $\leftrightarrow$ Critical Methodologies, 4(2), 152-197. https://doi.org/10.1177/1532708603262787

Hayes, A. F., \& Reineke, J. B. (2007). The Effects of Government Censorship of War-Related News Coverage on Interest in the Censored Coverage: A Test of Competing Theories. Mass Communication and Society, 10(4), 423-438. doi:10.1080/15205430701580581 
Katz, A. Z. (2017). Public Opinion and Foreign Policy: The Nixon Administration and the Pursuit of Peace With Honor in Vietnam. The Vietnam War, 109-126. doi:10.4324/9781351144889-6

Kiska, T. (2001, October 12). Satellite alters war coverage: Media wrestle with problem of what is news. Detroit News, p. 2 A.

Knightley, P. (2002). Losing friends and influencing people. Index on Censorship, 31(1), 146155.

Konstantinidou, C. (2008). The spectacle of suffering and death: The photographic representation of war in Greek newspapers. Visual Communication, 7(2), 143-169. doi:10.1177/1470357208088756

Kull, S. Ramsay C \& Lewis, E (2004). Misperceptions, the Media and the Iraq War. Political Science Quarterly, 114(4) Retrieved from http://www.jstor.org/stable/30035697

Lewandowsky, S., Stritzke, W. G. K., Freund, A. M., Oberauer, K., \& Krueger, J. I. (2013). Misinformation, disinformation, and violent conflict: From Iraq and the "War on Terror" to future threats to peace. American Psychologist, 68(7), 487-501.

http://dx.doi.org/10.1037/a0034515

Lewis, C. \& Reading-Smith, M. (2008). Iraq-The War Card: Orchestrated Deception on the Path to War.

Lippmann, W. (1922). Public opinion. New York: Harcourt, Brace and Co.

McCombs, Maxwell. Setting the agenda: Mass media and public opinion. Malden, MA: Blackwell Publishing, 2004. Web. 16 May 2016.

Morris, J. S. (2005). The Fox News factor. Harvard International Journal of Press/Politics, 10(3), 56-79.doi:10.1177/1081180x05279264

Mueller, J. (2005) The Iraq syndrome, 84 Foreign Affairs

Mueller, J. E. (1973). War, presidents, and public opinion. New York: Joh Wiley.

Newport, F., \& Carrol, J. (2005, August 24). Iraq versus Vietnam: A comparison of public opinion. Retrieved from https://news.gallup.com/poll/18097/iraq-versus-vietnamcomparison-public-opinion.aspx 
Noelle-Neumann, E. (1974), The Spiral of silence A Theory of public opinion. Journal of Communication, 24: 43-51. doi:10.1111/j.1460-2466.1974.tb00367.x

Okrent, D. (2004, May 30). THE PUBLIC EDITOR; Weapons of mass destruction? Or mass distraction? Retrieved from https:/www.nytimes.com/2004/05/30/weekinreview/thepublic-editor-weapons-of-mass-destruction-or-mass-distraction.htm1

Patterson, O. (1984). An analysis of television coverage of the Vietnam war. Journal of Broadcasting, 28(4), 397-404. doi:10.1080/08838158409386549

Pew Research Center Staff, \& Pew Research Center. (2014, February 07). Iraq War media coverage. Retrieved from https://www.pewresearch.org/fact-tank/2011/02/03/iraq-warmedia-coverage/

Prochnau, W. (1997). Once upon a distant war. Random House Value Publishing.

Reese, S. D., \& Lewis, S. C. (2009). Framing the War on Terror: The internalization of policy in the US press. Journalism, 10(6), 777-797. https://doi.org/10.1177/1464884909344480

Romano, A., \& Albiniak, P. (2001, October 15). TV's balancing act. Online magazine of Broadcasting \& Cable. Retrieved October 10, 2005, from http://www.broadcastingcable. com/index.asp?layout $=$ story stocks \& articleld $=C A 177781 \&$ pubdate $=10 / 15 / 2001 \&$ $\underline{\text { stt }=001 \& \text { display }=\text { searchResults }}$

Robinson, M. (1976). Public affairs television and the growth of political malaise: The case of "The selling of the Pentagon". The American Political Science Review, 70(2), 409-432. Retrieved from http://www.jstor.org/stable/1959647

Society of Professional Journalists Ethics Code, Society of Professional Journalists, http://www.spj.org/ethicscode.asp, 2014

Scheufele, D. A. (1999). Framing as a theory of media effects. Journal of Communication, 49(1), 103-122.doi:10.1111/j.1460-2466.1999.tb02784.x

Skoler, M. (2009). Why the news media became irrelevant-and how social media can help. (n.d.). Retrieved from https://niemanreports.org/articles/why-the-news-media-becameirrelevant-and-how-social-media-can-help/ 
Snow, N., \& Taylor, P. M. (2006). The revival of the propaganda state: US propaganda at home and abroad since 9/11. International Communication Gazette, 68(5-6), 389407. https://doi.org/10.1177/1748048506068718

Sperry, B. O. (2006). The Press Edited by Geneva Overholser and Kathleen Hall Jamieson New York: Oxford University Press (Institutions of American Democracy Series), 2005. 473 pp. American Journalism, 23(2), 173-174. doi:10.1080/08821127.2006.10678018

Stoler, P. (1986) The war against the press: politics, pressure and intimidation in the 80 's p. 57.

Strupp, J. (2005, April 14). Bush to ASNE: Access must be balanced with security. Edi- tor \& Publisher. Retrieved from http://www. editorandpublisher.com/eandp/search/article display.jsp?

United States Department of Defense "Public Affairs Guidance on Embedding Media During Possible Future Operations/Deployments in the U.S. Central Commands Area of Responsibility," 3 Feb 2003, http://www.defenselink.mil/news/Feb2003/ d20030228pag.pdf Sec 2.C

"Vietnam War Commentary." All Things Considered, NPR. 27 Feb. 1968.

Wiggins, Bradley. (2018). Framing the Truth: U.S. Media Coverage during the War on Terror.

Wyatt, Clarence R. (2007) “The Media and the Vietnam War." The War That Never Ends. Ed. David L. Anderson, and John Ernst. University Press of Kentucky.

White House. (2006, September). National Strategy for Combating Terrorism. Retrieved from https://2001-2009.state.gov/s/ct/rls/wh/71803.htm 


\section{Appendix A}

\section{CODESHEET OF CONTENT ANALYSIS OF TELEVISED NEWS BROADCASTS}

Coder:

Story Number

Story Date:

(Reliability 1.00)

Story Headline or Title:

Type of Story:

(1) TV News Broadcast

TV News Story/Segment Origin:

(1) CBS

(2) NBC

(3) $\mathrm{ABC}$

TV News Story Length (Minutes and Seconds)

\section{Frames}

$\begin{array}{lcc}\text { Military Conflict } & \text { Present (1) } & \text { Absent (0) } \\ \text { American Patriotism } & \text { Present (1) } & \text { Absent (0) } \\ \text { Protest } & \text { Present (1) } & \text { Absent (0) } \\ \text { Economic Consequences } & \text { Present (1) } & \text { Absent (0) } \\ \text { National Security } & \text { Present (1) } & \text { Absent (0) } \\ \text { Violence } & \text { Present (1) } & \text { Absent (0) }\end{array}$




\section{Appendix B}

\section{CODEBOOK FOR CONTENT ANALYSIS OF TELEVISED NEWS BROADCASTS}

Coder ID: Coders will input their three initials for identification purposes.

Story Date: The date on which the story ran.

Story Headline or Title: Coders will indicate stated headlines for each story

\section{Type of Story:}

(1) TV News Broadcast

TV News Story Origin:

(1)CBS, (2) NBC, (3) ABC

Frames: Coders are asked to determine the presence or absence of the following list of frames, based on prior research, and to indicate if this frame is best characterized as being episodic or thematic. Additionally, coders are asked to indicate which of the sources from the above list discussed the content associated with these frames by writing the identification number of the source(s) in the space provided. The list of frames coded for are: The list of frames coded for are: (1) Military Conflict—frames that emphasize the military battle itself (2) American Patriotismframes that emphasize citizen's duties to support American decisions (3) Protest-frames that show individuals our groups, in the U.S. or abroad protesting or the discussion of protest of the war; (5) National Security-frames that emphasize public safety concerns in the United States. (6) Violence- frames that show any sort of graphic images or explain the death toll in any way. 


\section{Appendix C}

\section{Full List of Data Sets}

Military Conflict- Vietnam

\begin{tabular}{|c|c|c|c|c|}
\hline \multicolumn{5}{|c|}{$\begin{array}{l}\text { VAR00001* VAR00002 Crosstabulation } \\
\text { Count }\end{array}$} \\
\hline & \multicolumn{4}{|c|}{ VAR00002 } \\
\hline & & not & present & Total \\
\hline \multirow[t]{2}{*}{ VAR00001 } & not & 1 & 0 & 1 \\
\hline & present & 0 & 8 & 8 \\
\hline Total & & 1 & 8 & 9 \\
\hline
\end{tabular}

\section{Symmetric Measures}

\begin{tabular}{|c|c|c|c|c|c|}
\hline & & Value & $\begin{array}{c}\text { Asymptotic } \\
\text { Standard } \\
\text { Error }^{\mathrm{a}}\end{array}$ & $\underset{T^{b}}{\text { Approximate }}$ & $\begin{array}{l}\text { Approximate } \\
\text { Significance }\end{array}$ \\
\hline Measure of Agreement & Kappa & 1.000 & .000 & 3.000 & .003 \\
\hline $\mathrm{N}$ of Valid Cases & & 9 & & & \\
\hline
\end{tabular}

a. Not assuming the null hypothesis.

b. Using the asymptotic standard error assuming the null hypothesis.

American Patriotism- Vietnam

\section{VAR00001 * VAR00002 Crosstabulation}

\section{Count}

\begin{tabular}{llrrrr} 
& \multicolumn{4}{c}{ VAR00002 } & \\
& & not & present & Tota! \\
\hline \multirow{2}{*}{ VAR00001 } & not & 4 & 1 & 5 \\
\cline { 2 - 6 } & present & 0 & 4 & 4 \\
\hline \multirow{2}{*}{ Total } & & 4 & 5 & 9 \\
\hline
\end{tabular}




\section{Symmetric Measures}

\begin{tabular}{|c|c|c|c|c|c|}
\hline & & Value & $\begin{array}{c}\text { Asymptotic } \\
\text { Standard } \\
\text { Error }^{a}\end{array}$ & Approximate & $\begin{array}{l}\text { Approximate } \\
\text { Significance }\end{array}$ \\
\hline Measure of Agreement & Kappa & .780 & .202 & 2.400 & .016 \\
\hline $\mathbf{N}$ of Valid Cases & & 9 & & & \\
\hline
\end{tabular}

a. Not assuming the null hypothesis.

b. Using the asymptotic standard error assuming the null hypothesis.

Protest- Vietnam

\section{VAR00001* VAR00002 Crosstabulation}

Count

\begin{tabular}{|c|c|c|c|c|}
\hline & \multicolumn{4}{|c|}{ VAR00002 } \\
\hline & & not & present & Total \\
\hline \multirow[t]{2}{*}{ VAR00001 } & not & 7 & 1 & 8 \\
\hline & present & 0 & 1 & 1 \\
\hline Total & & 7 & 2 & 9 \\
\hline
\end{tabular}

Symmetric Measures

\begin{tabular}{lccccc} 
& Value & $\begin{array}{c}\text { Asymptotic } \\
\text { Standard } \\
\text { Error }^{\mathrm{a}}\end{array}$ & $\begin{array}{c}\text { Approximate } \\
T^{b}\end{array}$ & $\begin{array}{c}\text { Approximate } \\
\text { Significance }\end{array}$ \\
\hline Measure of Agreement & Kappa & .609 & .340 & 1.984 & .047 \\
\hline N of Valid Cases & 9 & & & & \\
\hline
\end{tabular}

a. Not assuming the null hypothesis.

b. Using the asymptotic standard error assuming the null hypothesis. 
Economic Consequences- Vietnam

\section{VAR00001 * VAR00002 Crosstabulation}

\section{Count}

\begin{tabular}{|c|c|c|c|c|}
\hline & \multicolumn{4}{|c|}{ VAR00002 } \\
\hline & & not & present & Total \\
\hline \multirow[t]{2}{*}{ VAR00001 } & not & 8 & 0 & 8 \\
\hline & present & 0 & 1 & 1 \\
\hline Total & & 8 & 1 & 9 \\
\hline
\end{tabular}

\section{Symmetric Measures}

\begin{tabular}{|c|c|c|c|c|c|}
\hline & & Value & $\begin{array}{c}\text { Asymptotic } \\
\text { Standard } \\
\text { Error }^{\mathrm{a}}\end{array}$ & $\underset{T^{b}}{\text { Approximate }}$ & $\begin{array}{c}\text { Approximate } \\
\text { Significance }\end{array}$ \\
\hline Measure of Agreement & Kappa & 1.000 & .000 & 3.000 & .003 \\
\hline $\mathrm{N}$ of Valid Cases & & 9 & & & \\
\hline
\end{tabular}

a. Not assuming the null hypothesis.

b. Using the asymptotic standard error assuming the null hypothesis.

National Security- Vietnam

\begin{tabular}{|c|c|c|c|c|c|}
\hline \multicolumn{6}{|c|}{ Symmetric Measures } \\
\hline & & Value & $\begin{array}{l}\text { Asymptotic } \\
\text { Standard } \\
\text { Error }^{\mathrm{a}}\end{array}$ & Approximate & $\begin{array}{l}\text { Approximate } \\
\text { Significance }\end{array}$ \\
\hline Measure of Agreement & Kappa & .727 & .247 & 2.268 & .023 \\
\hline$N$ of Valid Cases & & 9 & & & \\
\hline
\end{tabular}

a. Not assuming the null hypothesis.

b. Using the asymptotic standard error assuming the null hypothesis. 


\section{VAR00001 * VAR00002 Crosstabulation}

\section{Count}

\begin{tabular}{llrrr} 
& \multicolumn{2}{c}{ VAR00002 } & \\
& & not & present & Total \\
\hline \multirow{2}{*}{ VAR00001 } & not & 6 & 1 & 7 \\
\cline { 2 - 5 } & present & 0 & 2 & 2 \\
\hline \multirow{2}{*}{ Total } & & 6 & 3 & 9 \\
\hline
\end{tabular}

Violence- Vietnam

VAR00001* VAR00002 Crosstabulation

Count

\begin{tabular}{llrrrr} 
& \multicolumn{4}{c}{ VAR00002 } & \\
& & not & present & \multicolumn{1}{c}{ Total } \\
\hline VAR00001 & not & 1 & 1 & 2 \\
\cline { 2 - 6 } & present & 0 & 7 & 7 \\
\cline { 3 - 6 } Total & & 1 & 8 & 9 \\
\hline
\end{tabular}

Symmetric Measures

\begin{tabular}{lrrrrr} 
& Value & $\begin{array}{c}\text { Asymptotic } \\
\text { Standard } \\
\text { Error }^{{ }^{2}}\end{array}$ & $\begin{array}{c}\text { Approximate } \\
T^{b}\end{array}$ & $\begin{array}{r}\text { Approximate } \\
\text { Significance }\end{array}$ \\
\hline Measure of Agreement & Kappa & .609 & .340 & 1.984 & .047 \\
\hline N of Valid Cases & 9 & & & & \\
\hline
\end{tabular}

a. Not assuming the null hypothesis.

b. Using the asymptotic standard error assuming the null hypothesis. 
Military Conflict- Iraq

\section{VAR00001 * VAR00002 Crosstabulation}

Count

\begin{tabular}{llrrrr} 
& \multicolumn{5}{c}{ VAR00002 } \\
& & not & present & Total \\
\hline \multirow{2}{*}{ VAR00001 } & not & 1 & 1 & 2 \\
\cline { 2 - 6 } & present & 0 & 7 & 7 \\
\hline Total & & 1 & 8 & 9 \\
\hline
\end{tabular}

\section{Symmetric Measures}

\begin{tabular}{|c|c|c|c|c|c|}
\hline & & Value & $\begin{array}{l}\text { Asymptotic } \\
\text { Standard } \\
\text { Error }^{\mathrm{a}}\end{array}$ & Approximate & $\begin{array}{l}\text { Approximate } \\
\text { Significance }\end{array}$ \\
\hline Measure of Agreement & Kappa & 1.000 & .000 & 3.000 & .003 \\
\hline$N$ of Valid Cases & & 9 & & & \\
\hline
\end{tabular}

a. Not assuming the null hypothesis.

b. Using the asymptotic standard error assuming the null hypothesis.

American Patriotism- Iraq 


\section{VAR00001 * VAR00002}

Crosstabulation

\section{Count}

\begin{tabular}{lcrr} 
& & $\begin{array}{c}\text { VAR00002 } \\
\text { present }\end{array}$ & \multicolumn{1}{c}{ Total } \\
\hline VAR00001 & present & 9 & 9 \\
\hline Total & & 9 & 9 \\
\hline
\end{tabular}

Symmetric Measures

\begin{tabular}{lrr} 
& \multicolumn{2}{c}{ Value } \\
\hline Measure of Agreement & Kappa &.$^{\mathrm{a}}$ \\
\hline N of Valid Cases & & 9 \\
\hline
\end{tabular}

a. No statistics are computed because VAR00001 and VAR00002 are constants. 
Economic Consequences

\section{VAR00001 * VAR00002 Crosstabulation}

Count

\begin{tabular}{llrrrr}
\multicolumn{5}{c}{} & \multicolumn{2}{c}{ VAR00002 } \\
& & not & present & Total \\
\hline \multirow{2}{*}{ VAR00001 } & not & 6 & 0 & 6 \\
\cline { 2 - 6 } & present & 0 & 3 & 3 \\
\cline { 3 - 6 } & & 6 & 3 & 9 \\
\hline \multirow{2}{*}{ Total } & & & &
\end{tabular}

Symmetric Measures

\begin{tabular}{|c|c|c|c|c|c|}
\hline & & Value & $\begin{array}{l}\text { Asymptotic } \\
\text { Standard } \\
\text { Error }^{\mathrm{a}}\end{array}$ & Approximate & $\begin{array}{l}\text { Approximate } \\
\text { Significance }\end{array}$ \\
\hline Measure of Agreement & Kappa & 1.000 & .000 & 3.000 & .003 \\
\hline N of Valid Cases & & 9 & & & \\
\hline
\end{tabular}

a. Not assuming the null hypothesis.

b. Using the asymptotic standard error assuming the null hypothesis.

National Security- Iraq

\section{VAR00001 * VAR00002 Crosstabulation}

\section{Count}

\begin{tabular}{lcrc} 
& & VAR00002 \\
& & present & Total \\
\hline VAR00001 & present & 9 & 9 \\
\hline Total & & 9 & 9 \\
\hline
\end{tabular}




\section{Symmetric Measures}

\begin{tabular}{lcr} 
& \multicolumn{2}{c}{ Value } \\
\hline Measure of Agreement & Kappa &.$^{\mathrm{a}}$ \\
\hline N of Valid Cases & & 9 \\
\hline
\end{tabular}

a. No statistics are computed because

VAR00001 and VAR00002 are constants. 